\title{
Interpreting mega-development projects as territorial traps: the case of irrigation schemes on the shores of Lake Chad (Borno State, Nigeria)
}

\author{
Marina Bertoncin and Andrea Pase \\ Dipartimento di Scienze Storiche, Geografiche e dell'Antichità, Università di Padova, via del Santo 26, \\ 35123, Italy \\ Correspondence to: Andrea Pase (andrea.pase@unipd.it)
}

Received: 2 December 2016 - Revised: 16 March 2017 - Accepted: 2 May 2017 - Published: 13 June 2017

\begin{abstract}
From the colonial era up to the present, mega-irrigation projects for agriculture have played a key role in the production of state space in Sahelian Africa. Transferring a concept proposed by Agnew (1994) onto a different scale, it is possible to interpret these mega-projects as "territorial traps". In fact, they set up boundaries (physical, relational, cognitive and operative) that force evolutive trajectories of the areas involved along rigid pathways. In the aftermath of the systematic failure of the mega-projects, farmers are faced with constraints determined by the trap imposed, without having any of the promised benefits in terms of productive growth, i.e. income. In many situations, the farmers have identified "a means of escape" from these catastrophes by transgressing the boundaries imposed by the territorial traps and reintroducing parts of the infrastructure to a common use. The case study traces the crisis, and ultimately the failure, of the mega-irrigation projects constructed in the 1970s along the shores of Lake Chad in Nigeria.
\end{abstract}

\section{Introduction}

"Territorial trap" was defined in 1994 by Agnew in a seminal article that has left its mark on contemporary political geography debates (Agnew, 1994, 2010, 2015; Brenner and Elden, 2009; Reid-Henry, 2010; Newman, 2010; Elden, 2010, 2013; Shah, 2012). According to Agnew, the advent of the modern territorial state involves three geographical assumptions: sovereignty is defined in territorial terms (the state is understood as a unitary stable sovereign space); political space is polarized between internal and external (between the internal policy of the state and the international); and the state becomes a uniform container of the society. These assumptions, which may seem at the same time essential and taken for granted, have instead created an intellectual trap by losing sight of the need for other modalities different from a territorial state, such as considering and studying political space as networks/flows and place making (Agnew, 2015). Since then, many ways have been proposed to escape this trap in order to be able to confront with more intellectual freedom the forms of political institutions on a global scale.
In this article, we are adopting the metaphor of Agnew, which is effective, yet we are proposing a shift: to transfer the concept of territorial trap from a general viewpoint of modern political space and international relations into a different spatial setting - the internal one.

The transposition of territorial trap into a different dimension seems justified, keeping in mind that double movement, according to Lefebvre (1991), establishes the production of state space: it acts to place space on a homogenous unitary grid and, at the same time, it determines fragmentation of space. The production of modern political space - the state - follows the principals of "Hobbesian spatial logic" (Galli, 2001:28). It is an "abstract space" (Lefebvre, 1974; Stanek, 2008) made "smooth" through the removal of any previous social content or of any possible autonomy. This abstract space is "odd": "It is at once homogeneous and compartmentalized. It is also simultaneously limpid and deceptive; in short, it is fraudulent" (Lefebvre, 1991:310). So, one can say that this abstract space is fraudulent, exactly as a trap. It has a double character, both homogeneous and fractured: "Under its homogeneous aspect, space abolishes distinction 
and differences ... simultaneously, this same space is fragmented and fractured, in accordance with the demands of the division of labour and the division of needs and functions" (Lefebvre, 355). The cancellation of internal differences allows for the creation of political-territorial unity: the states, abstract homogenous spaces internally and yet similar from a political-logical point of view can, in this way, be mutually recognized on the international relations scene. Simultaneously, the state fragments the internal space into smaller units and creates a hierarchy between them. This further leads to "discrete, integrated, bounded, and coherent" units, intended to naturalize and to conceal the intervention of the state on society, besides providing "sites for capitalist accumulation" and containers adapted for political-economic development (Brenner and Elden, 2009:369).

Although up to now the discussion regarding the state territorial trap has been mainly focused on the first movement (the production of a political space that is abstract and homogenous), we believe it is likewise interesting to investigate the second movement concerning internal fragmentation.

In particular, our specific reference is hydro-agricultural mega-projects in the Sahelian area. Mega-projects (Gellert and Lynch, 2003:15-16) transform space "rapidly, intentionally, and profoundly in very visible ways, and require coordinated applications of capital and state power. They use heavy equipment and sophisticated technologies usually imported from the Global North and require coordinated flows of international finance capital". Specifically, the largescale Sahelian irrigation schemes consist of infrastructures for water catchment (dams, pumping stations) and for distribution through networks of canals that allow for irrigation over extensive areas, with the clear objective of guaranteeing agricultural production in hostile climatic conditions (scarcity and uncertainty of precipitation). As Sautter affirms (1987:5), "Hydro-agricultural interventions have value as quasi-experimental objects" because from them "autonomous operational realities emerge that can be individualized and delimitated". The mega-dimension exalts these characteristics, bringing even more into evidence the new "techno-spatial order". Precisely for this reason, the "spectacular developments" and the "vast irrigation networks" are favoured by governments (Sautter, 1987:9).

The era of mega-irrigation projects in Sahel began in colonial times with Gezira (in Anglo-Egyptian Sudan), departing from the Sennar Dam on the Blue Nile (Gaitskell, 1959; Barnett, 1977), and with the Niger Office in French Sudan, departing from the Markala dam on the Niger River (Morabito, 1977, 1995). Two other great Sahelian hydraulic systems were also involved during the colonial era, the Senegal river (Maïga, 1995) and Lake Chad (Bouquet, 1990; Magrin, 2009; Bertoncin and Pase, 2012), although on a smaller scale. The aim of the projects was to bring what the French colonizers called mise en valeur, meaning to exploit colonial resources to reinforce the economy of the colonial countries: the most evident was Gezira, which supplied cotton for the English textile industry.

With independence irrigated areas continued to expand: the aim of the independent states was to ensure food selfsufficiency or, at least, in the regions that were afflicted the most by famine, to safeguard food security for its people. But there were clear political reasons (to legitimize the young states by consolidating the visibility within the space) and economic motivations (to develop market economies for exportation). Between the 1960s and the 1980s, it seems there was a rapid expansion of schemes: large dams multiplied, such as Roseires on the Blue Nile or Manantali on a tributary of Senegal. It should be clarified that agricultural irrigation in Sahel is not limited to state mega-projects. In fact, over time other interventions appeared with yet other dimensions, such as small-scale village irrigation projects, and with other actors such as NGOs or private investors. Choices such as size, technologies, types of production and forms of management are so diversified that different pathways are created which are dependent on the geographical context, social conditions, markets, governments and international development agency decisions. In this regard, Kuper (2011) identifies three distinct phases: the first (from the 1960s to the early 1980s) is noted as the peak of top-down mega-irrigation; the second (1980s-1990s) moves towards community capacity-building in a bottom-up approach, which then, at the turn of the millennium, lead to a "new narrative founded on markets". In the most recent phase, there is, on the one hand, a spreading of large investments, above all by foreigners, in Sahelian land (water and land grabbing) and, on the other hand, an uncontrolled proliferation of individual initiatives of small entrepreneurs which then generates a risk of over-exploitation and conflicts in the appropriation of the resources.

In any case, for a long time the mega-project was a reference model for the expansion of agricultural irrigation in the Sahel and, for the purposes of our study, it was a type of hydro-agricultural intervention that permitted us to highlight the role of the states and the territorial and cultural transformations that it brought about. Pascon (1978) so evocatively described it as a passage "of water from the sky to water of the state".

These irrigation mega-projects are bounded territorial units. Although on a reduced scale, the projects conformed homogeneously within the state territory: (1) they defined regulatory limits (Boone, 2014, defined it as "statist land tenure regime"); (2) they established a clear separation between internal and external; and (3) they functioned as a container for economic and social processes (in that the container gave form to these processes). There is, therefore, a clear similarity of function between the two movements of homogeneousness and fragmentation of space: they both constitute a territory.

With this now clear, we can investigate how these territorial units "entrap" space, society and the economy and which, consequently, determine their path of development. In other 
words, we can try to understand "how the territorial trap is actually constructed and reproduced, whether in social science, statecraft, politics or everyday life" (Brenner and Elden, 2009:354).

The boundaries of the mega-projects - the physical features, the relational, the cognitive and the operative - become fixed and are maintained over time. In this process, the projects acquire the characteristics of obduracy and stability as defined by Hommels (2005) in his discussion of cities in the STS studies.

At this point it becomes important to understand how these territorial traps function. In the second section, we will propose some theoretical reflections on irrigation projects understood as territorial traps, which will be interpreted utilizing the category of "apparatus" proposed by Foucault (1994) and recalled by Agamben (2009). In the third section, the modalities for the planning, implementation and organization of the mega-irrigation projects are analysed. In order to observe first hand how a territorial trap is constructed, a case study of the irrigation schemes in the region of Lake Chad (Borno, Nigeria) was selected (Bertoncin and Pase, 2012, 2015). In the fourth section, through an historical reconstruction of what happened during these projects, one comes to understand how rapidly it steered them to the path of failure (Hirschman, 1967; Scott, 1998). Finally in the fifth section, a discussion follows as to what measures the farmers managed to put into place to escape from the territorial trap. The recent thoughts of Agamben (2015) on the crisis of (political) action and the possible means of escape contributed to our analysis.

\section{Irrigation projects, apparatuses of development, territorial traps}

The mega-irrigation projects are an example of a "development apparatus" (Ferguson, 1990; Sidaway, 2007) set into place through the systematic application of scientific expertise and by the organization and technical competence coming from the Global North, all of which are established in order to accelerate the modernization process in contexts considered backward.

It seems useful to examine in more depth the concept of "apparatus" as defined by Agamben (2009). The author begins with a 1977 interview of Foucault. In a crucial passage, Foucault confirms that an apparatus is a network of connections that is present in various heterogeneous elements (discourses, institutions, physical structures, rules and scientific proposals): "A kind of a formation, so to speak, that at a given historical moment has as its major function the response to an urgency. The apparatus therefore has a dominant strategic function ... which means that we are speaking about a certain manipulation of relations of forces, of a rational and concrete intervention in the relations of forces, either so as to develop them in a particular direction, or to block them, to stabilize theme, and to utilize them. The apparatus is thus always linked to certain limits of knowledge that arise from it and, to an equal degree, condition it" (Foucault, 1994, in Agamben, 2009:2, our italics).

In the irrigation mega-projects, all of the following characteristics exist. (1) They are made up of many heterogeneous elements connected in a network of relationships that enable them to function productively (discourses related to development and modernization, board and management structures; farmer associations for allottees, etc.; dams, canals, pumping stations, rules for the use of water and agricultural management; and assumptions by agronomic, pedologic and hydraulic sciences). (2) They have a historical function by responding to an urgency (in reality very urgent, which transforms itself over time, such as the colonial mise en valeur, the food self-sufficiency of the independent states, then the food security of its populations and the humanitarian emergency during the great droughts, and nowadays the climate change and the implementation of the capacity for resiliency). (3) They evolved from power relationships (between the state and the local society, among officials, technicians, allottees, etc.). (4) They are founded on a specific knowledge that marginalizes others (modern vs. traditional knowledge; formal knowledge vs. informal/tacit).

Agamben examines in more depth the Foucauldian proposal by suggesting "a general and massive partitioning of beings into two large groups or classes: on the one hand, living beings (or substances) and, on the other, apparatuses in which living beings are incessantly captured" (2009:13, our italics). Therefore, an apparatus is "literally anything that has in some way the capacity to capture, orient, determine, intercept, model, control, or secure the gestures, behaviours, opinions, or discourses of living beings" (2009:14, our italics).

In the citations of Foucault and of Agamben (we have highlighted them in italics), there is a repetition of the verbs to block, to capture and to intercept, reverting back - through another means - to the metaphor of a trap. In fact, the definition of trap is exactly that of an "apparatus that allows for capture". Assuming this point of view, we can thereby affirm that a mega-irrigation project functions as a trap: one that intercepts and blocks space, relationships, knowledge and organizations.

In order to comprehend the diverse components of the Sahelian mega-projects as territorial traps, we thought it would be useful to make a distinction between the two different levels. The first level refers to territorial characteristics and the second to the functional modality of the trap.

At the first level - from a territorial perspective - two fundamental aspects are evidenced: the physical and the relational. First and foremost is the physical dimension: they are clearly defined spaces where the transformative capability of modern technology radically modifies the profile of the land, the hydrographical network and the vegetation in order to set in place a geometrical partition of space and the total con- 
trol of whatever enters or leaves (water, people, production). Then there is the relational dimension: the territory of the project is the go-between for specific political and social relations. The mega-project is a space where modern institutions act (the state, the ministers, the corps of technical assistants, international construction companies and international aid organizations) and, in this way, marginalize and delegitimize the local institutions (for example, traditional elders), who are viewed as irrelevant, if not as an obstacle, to modernization. The former have written rules, legal statutes and formalized procedures; in contrast, the second are based on customs that are not legally recognized or, if they are, only considered as an auxiliary function, a procedure that appears to outsiders as confusing and unclear. The roles and the positions of power determined by the hierarchy of the project invalidated the roles and positions of local authority. These institutional roles were set up to "mediate" and to deal with power relationships between individuals within the territory.

From the point of view of how the apparatus functions, understood as a trap, there are two other essential aspects: the cognitive and the operative dimension.

Concerning the cognitive dimension, a project is established through scientific expertise coming from the Global North that marginalizes local knowledge relative to the soil, to the water and to ways of cultivating and of extracting resources from the environment (for example, fishing or transhumance). Then there is the operative dimension that follows functional procedures and practices: water shifts, imposition of monocultures or of specific crop rotation, decisions regarding the agricultural calendar and control over the stages of production. Whatever happens within the perimeter of the project, such as agricultural practices and the transformation of products, is determined and imposed from above.

In this way, the territorial trap is deployed (Table 1): the water is dammed and channelled into geometric networks whose distribution is regulated in time and quantity; the roles tied to the project focus on power plays that, at least initially, are binding and not negotiable; and local expertise and traditional practices are excluded from the mega-projects. The trap worked, and the intruder - whoever or whatever did not conform to the modern agricultural plan - was thrown out: the floods, the wetlands, the local institutions, the knowledge embedded in the land and in the resources, and the agricultural, pastoral and fishery practices of the populations. In the meantime, all those that are part of the project from the technicians to the allottees, although with varying degrees of power, are in turn captured: totally dependent on the project than can fire them or can take away their land.

Even if the period of the mega state-operated irrigation schemes in Sahelian Africa, which began in colonial times, had reached its apex between the 1960s and the 1980s, this does not mean that the mega-project per se is dead. Today it still represents an example of major investment in land projects with foreign capital, often in alliance with national investors. It has redefined the role of the state from being the main protagonist to one of a "facilitator" for investments. It is possible to observe this phenomenon in Mali at the Office of Niger (for example Malibya) or along the Nile in Sudan (Quatrida, 2015; Bertoncin et al., 2017).

In the next section, we analyse a case study of irrigation projects interpreted as territorial traps.

\section{The irrigation mega-projects of Lake Chad (Borno State, Nigeria): how a territorial trap is put into place}

The diffusion of irrigation schemes is a vast phenomenon; so daunting that one can distinguish it as one of the principal factors responsible for the spatial transformation of Sahelian Africa. Precisely for the breadth of the areas concerned and for the multiple national contexts involved, the time and the modalities of implementation of the irrigation schemes in the four major hydrographic basins (the Senegal, Niger, Nile and Lake Chad) differed. Our field research covered a span of more than 20 years, from Senegal up to Sudan. In particular, our research concentrated on the region of Lake Chad. It began in 2000 and continues up to the present time, involving all four of the countries along its borders ${ }^{1}$. We investigated the origin and the development of Sahelian agricultural irrigation through semi-structured interviews which included field observations and were repeated over time (with technicians, supervisors and workers of the projects; the allottees; the farmers, breeders and customary heads of areas near the projects; merchants; workers of international organizations and NGOs; representatives of farmer associations; colleagues at regional universities and research specialist centres, etc.). Our documentation included grey literature, maps, photographs and iconographic illustrations. With all these contributions, we decided to focus our attention on this specific case study in order to understand concretely the processes that were put into place. In our opinion, the case study taken into consideration is particularly significant because of the mega-dimension of the project. The installation, which took place in a very short period of time, introduced a vast range of advanced technologies in a peripheral area without any previous experience with modern irrigation. These characteristics gave us the possibility to expose and to provide evidence for the construction and operative procedures of a territorial trap.

In the 1970s an intense program for the extension of irrigation schemes (Fig. 1) was developed in the land surrounding Lake Chad in the state of Borno (Adams, 1991; Bertoncin and Pase, 2012, 2015; Blench, 1997). From 1970 to 1984 Nigeria, thanks to income gained through petroleum production, had significant resources available that they could also direct towards the modernization of agriculture. In the north-

\footnotetext{
${ }^{1}$ At this time the absence of even a minimum standard for safety and security made it impossible to access a large area that was part of our research in the region.
} 
Table 1. The irrigation projects as territorial traps.

\begin{tabular}{|c|c|c|c|c|}
\hline & $\begin{array}{l}\text { Physical } \\
\text { dimension }\end{array}$ & $\begin{array}{l}\text { Relational } \\
\text { dimension }\end{array}$ & $\begin{array}{l}\text { Cognitive } \\
\text { dimension }\end{array}$ & $\begin{array}{l}\text { Operative } \\
\text { dimension }\end{array}$ \\
\hline Type of closure & $\begin{array}{l}\text { The network of canals, } \\
\text { barriers and check } \\
\text { points, administrative } \\
\text { and operational centres, } \\
\text { and new settlements: } \\
\text { the } \\
\text { physical closure }\end{array}$ & $\begin{array}{l}\text { The projects' institu- } \\
\text { tions, the social role } \\
\text { s that derive from them } \\
\text { (who commands, who } \\
\text { monitors, who obeys): } \\
\text { the relational closure }\end{array}$ & $\begin{array}{l}\text { Survey, feasibility } \\
\text { studies, topographic } \\
\text { and thematic maps: the } \\
\text { cognitive closure }\end{array}$ & $\begin{array}{l}\text { Organizational pro- } \\
\text { cedure (who does } \\
\text { what and when): the } \\
\text { operative closure }\end{array}$ \\
\hline $\begin{array}{l}\text { Who/what is } \\
\text { included }\end{array}$ & $\begin{array}{l}\text { "Useful" water, } \\
\text { crop selection, } \\
\text { allottees/technicians } \\
\text { and officials }\end{array}$ & $\begin{array}{l}\text { Relationships initiated } \\
\text { with the project and } \\
\text { functional to it (verti- } \\
\text { cal or horizontal); writ- } \\
\text { ten rules }\end{array}$ & $\begin{array}{l}\text { Technical and scientific } \\
\text { expertise }\end{array}$ & $\begin{array}{l}\text { Agricultural } \\
\text { modernization: produc- } \\
\text { tion organization, pro- } \\
\text { cessing and marketing } \\
\text { of product }\end{array}$ \\
\hline $\begin{array}{l}\text { Who/what is } \\
\text { excluded }\end{array}$ & $\begin{array}{l}\text { Floods, wetlands; } \\
\text { vegetation and natu- } \\
\text { ral fauna/local crop } \\
\text { varieties; villages; } \\
\text { herds }\end{array}$ & $\begin{array}{l}\text { Local social and politi- } \\
\text { cal relations; customs }\end{array}$ & $\begin{array}{l}\text { Contextual/tacit } \\
\text { knowledge }\end{array}$ & $\begin{array}{l}\text { Polyculture, trans- } \\
\text { humance, other produc- } \\
\text { tive and commercial } \\
\text { practices }\end{array}$ \\
\hline $\begin{array}{l}\text { The trap in action: } \\
\text { who/what is stan- } \\
\text { dardized? How it is } \\
\text { standardized? }\end{array}$ & $\begin{array}{l}\text { Geometric partition } \\
\text { of the space (canals, } \\
\text { fields, roads), water } \\
\text { regulation, levelling } \\
\text { of land, planning of } \\
\text { production spaces and } \\
\text { settlements }\end{array}$ & $\begin{array}{l}\text { Governing of relations: } \\
\text { command and control }\end{array}$ & $\begin{array}{l}\text { Forced/imposed learn- } \\
\text { ing; vulgarization (dif- } \\
\text { fused through simplifi- } \\
\text { cation) of modern ex- } \\
\text { pertise }\end{array}$ & $\begin{array}{l}\text { Water shifts, techniques } \\
\text { and timing of agricul- } \\
\text { tural operations }\end{array}$ \\
\hline
\end{tabular}

eastern region, an ambitious territorial plan was designed that responded to the rapid, non-regulated urban expansion of the capital in Maiduguri. The plan was to develop agricultural irrigation in order to resettle a sizeable part of the population and to consolidate the local economy in what was considered a strategic area along the borders. At the same time, the heavy droughts of 1973 and 1984 affected the Sahelian region. On the one hand, these droughts made the irrigation projects even more crucial; on the other hand, they caused serious problems.

The main area of interest was the zone along the shore of the lake where water could be drawn when necessary through intake channels. In particular, there were three planned interventions: two "polders" (areas of seasonal flooding from the lake that needed to be contained by dams to "defend it" from the overflow of the lake) and a major irrigation scheme further back from the shores of the lake. The two twin polders needed to have 20000 ha of extension: only one of the two was actually started, the Baga Polder, while the second one, the Kirenowa Polder, was not able to pass the feasibility study. As concerns the first polder, it was designed in 1973 for the Baga Kawa area. Construction began in 1977: a sheet of iron $32 \mathrm{~km}$ long was constructed in order to protect the area from the seasonal flooding of the lake. A $13.5 \mathrm{~km}$ channel conducted water from the lake. In this area, floodrecession agriculture was practiced on a small scale in addition to rainfed cultivations; it became more relevant after the drought of 1973 and particularly after that of 1984 . Activities such as livestock transhumance and fishing were also important.

Indisputably, the South Chad Irrigation Project (SCIP) designed in 1972 (Fig. 2) was the most significant (Adam, 2004; Bertoncin and Pase, 2012; Blench, 1997; Kalawole, 1987, 1988; Ogunbameru, 1986). The area decided upon was a plain made up of thick layers of clay with irregular strands of sand and lime, annually affected by flooding from the smaller tributaries of the lake, the Yedseram and the Ebeji. About 28000 acres were used for traditional cultivation even though the land actually cultivated depended on the level of seasonal floods. Above all, transplanted grain sorghum (musakwa) was cultivated. Traditional methods of containment and conservation of water of the land testifies to the fact that the local farmers were capable irrigators. In the sandy humps, millet, onions, okra and peanuts were grown. Working in the fields was socially accepted, even though the hardest work was willingly entrusted to external workers. Traditional elders regulated the task of assigning land parcels. Cattle investment was a privilege above all other forms of 


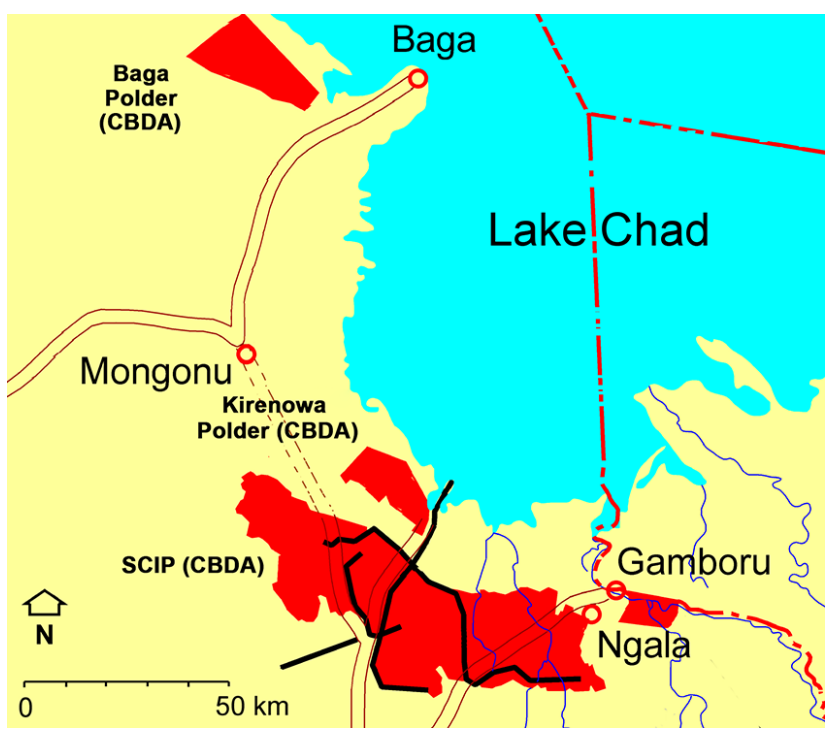

Figure 1. Irrigation projects surrounding Lake Chad with their main channels as planned in the early 1970 s by the Chad Basin Development Authority (CBDA). Only a small part of this ambitious plan was accomplished.

accumulation of wealth. Fishing was integrated with cultivation and breeding. There were 18 villages in the area. The principal ones were Marte, Missene and Ala with a combined population of about 8500. The intensely cultivated plain seemed dotted with trees: the idea that appeared to developers was that this was a place that exhibited a positive path of integration between human activities and environmental resources settled over a long period of time. A survey carried out during the feasibility studies (1971-73) claimed that it had an environmental "sensitivity", which encapsulated man-nature relationships. It appeared to be a "developed" and "self-sufficient" area with regard to food requirements and artefacts of primary need, something to absolutely maintain (FAO, 1973).

The SCIP needed to take advantage of the potential irrigating of Lake Chad by keeping all the suitable land within the perimeter, thus passing from one to two harvests a year. The agricultural mechanization, electrification and the industrial manufacturing and marketing of products on a regional scale were the cornerstones of intervention. The basic harvests were wheat, rice and cotton. Other than the construction of channels and a system of pumping stations and installations for the processing of products, a plan was put into place for setting up settlements and for establishing a network of roads operating to unite the territory, without forgetting that it would provide a connection to the state capital, Maiduguri. It was expected that the combined population would grow in 2010 to 220000 (where originally there were only 10000). The project was divided into three parts, to be completed one after the other. The first phase, which began in 1975, provided for the building of the main infrastructures: a $29 \mathrm{~km}$

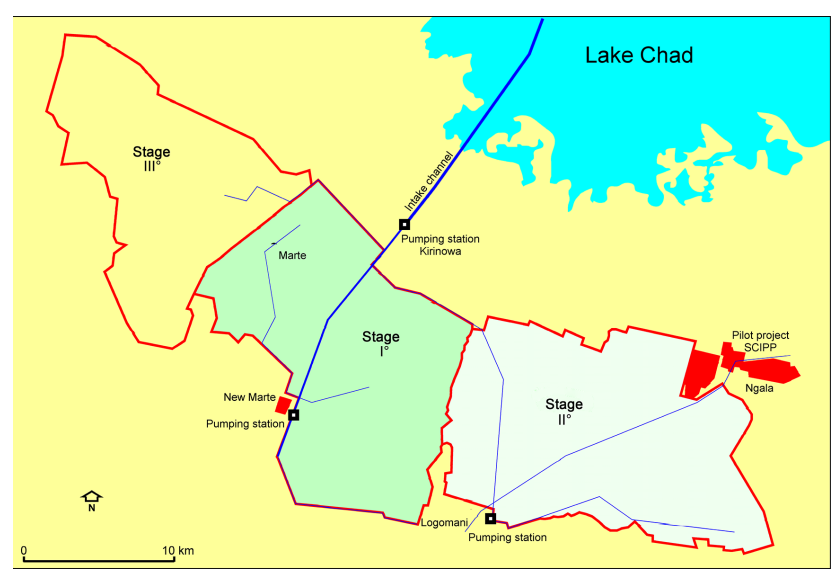

Figure 2. South Chad Irrigation Project (SCIP). Only Stage I and parts of Stage II were actually implemented.

intake channel that would reach the principal pumping station at Kirinowa. From there the main canal of $13 \mathrm{~km}$ would arrive at the pumping station at Gadadai, which in turn would pump and distribute water through a gravity network.

In our interpretation these two projects (Baga Polder and SCIP) functioned as territorial traps. Our analysis will demonstrate how the four dimensions as identified in Sect. 2 - the physical, relational, cognitive and operative - were implicated in the construction of these apparatuses.

First and foremost, these irrigation schemes define a precise physical space: the iron barrier of the Baga Polder is the most evident example. The riverbanks and the canal networks distinctly separate what is inside from what is outside. On the inside, only what is provided for and established as necessary for agro-industrial production is allowed: the offices, the warehouses and the "modern" villages where the allottees live. All is new and modern, beginning with the recently built SCIP central office situated in New Marte. The water from the lake is distributed according to scheduled timetables and the means predefined by predetermined channels and pumping stations in order to have water where, how much and when it is needed. The natural floods are kept outside. In this way, only certain crops could be cultivated, wheat and rice above all. Traditional crops were banned. Herds were kept on the outside and moved away from their habitual grazing lands. In 1977, a most significant observation was made by a French geographer, Bouquet, who visited the village of Allagarno in the area of Baga (1990 II:195). He described how the kulo-sadié, the recessional agriculture fields of the village, were abandoned by the farmers. The year before "a group of topographers belonging to the Baga Polder Project came and marked off with sticks the area usually occupied by the kulo-sadié of Allagarno without giving them any compensation or explaining to the farmers the reasons behind their actions" (Bouquet, 1990 II:195). From that time, the farmers did not want to return to their fields so as not to re- 
move the sticks and not to be forced to work on land "poisoned by the products of progress". Even before the beginning of the project, when only the sticks marked off the area, the process of excluding traditional cultivation had already begun. The physical boundary even worked when it had not yet been erected.

Secondly, new power relationships are established: relational boundaries are formed and dominated by powerful actors (Bertoncin and Pase, 2012). The managers, the technicians and the experts occupy all the positions of power in the irrigation scheme. An iron discipline is imposed and the chain of command is very clear. The organizational hierarchy reverberates in the social hierarchy: the visible signs (the automobiles, the houses larger and beautiful, etc.) are characteristic of the board. Only the functional relationships of the projects are accepted. Family relationships and ethnic groups are excluded. The allottees are only chess pawns in the project: the workforce. Their particularities are not taken into consideration or have any value: not their ethnic origins, opinions, working skills or even food preferences. The written rules for the operating procedures of the project are not open for discussion. No possibility is given to them to refer back to personal values and different customs. The relational boundary is well defined: everyone knows who commands and everyone knows the rules.

Thirdly, the projects delimit a cognitive boundary. Modern techno-scientific expertise is mobilized right from the survey phase: studies regarding demography, pedology, hydrology, climatology, agronomy and economics record and classify all the data. Project construction is entrusted to engineers in the West. The operation of the project is based on modern agronomic knowledge, utilizing agricultural equipment, electricity, etc. Foreign technicians are summoned to begin the project. In particular, all local expertise is excluded, all the knowledge regarding the land, the rhythm of water and the cultivable species that are developed over time by the inhabitants. The tacit knowledge (Polanyi, 1966) that is able to create a positive relationship within the environment, which even the surveys recognized, is not taken into consideration at all.

Finally, the projects set up an operational boundary. Everyone within the scheme has a role to play, a job to do. Everyone inside the scheme has predetermined schedules, rigidly timed. Ploughing of the fields, seeding, fertilizing, cleaning out the weeds, harvesting and with supervision against granivorous birds: all is timed and controlled from above. The allottees are obliged to carry out their work according to the field inspectors' instructions. In particular, the water timetable has to be rigorously respected in order to avoid uneven distribution and difficulty of distribution. If the allottees have difficulty in carrying out their roles, they are accused of being lazy and can be replaced in the next season. In other words, what local farmers do well (polyculture, the integration among different activities such as agriculture, breeding and fishing) are undesired in the project and considered an obstacle.

Analysis of the four dimensions (physical, relational, cognitive and operative) confirms that these projects are clearly territorial traps as defined in Sect. 2: the projects entrap the local people and the farmers by delimitating specific paths for development and excluding any alternative. On many occasions (not only here but also in other areas of our research), the farmers commented: "We are prisoners of the project". They feel entrapped by an organizational structure that forces specific production and cultivation practices but without giving them adequate support. In the next section, the results of these projects - not positive - will be presented, seeking to understand whether one of the reasons for their failure is that they are indeed territorial traps.

\section{How territorial traps are dismantled}

In colloquial language, "trap" has a particular meaning. In fact, it can be used to refer to any mechanism that performs poorly or does not live up to the expectations of its user. It is curious that a device that is as potentially as dangerous as a trap (that imprisons, immobilizes, restrains and subjects the ones captured to the will of the constructor) becomes another way of saying failure, for something is not working or that blocks itself.

The irrigation projects of Borno also become traps in this particular interpretation. They do not function and completely fail expectations.

Both projects were conceived as a means of taking advantage of the water draining from the lake through intake channels. But Lake Chad is mutable and unpredictable. Not very deep (no more than 3 or $4 \mathrm{~m}$ ), the surface of this endorheic basin varies rapidly depending on how much water drains out from the overflow of the Chari River, its principal tributary ( $88 \%$ of the intake derives from this river). In as much as the floods are extremely variable, the borders of the lake fluctuate in continuation, so much so that, in effect, there are three Chad lakes, depending on the level of water: the Small, the Medium and the Great Chad (Lemoalle, 2015). In the 20th century, the Small and Medium Chad alternated. The projects were designed for the conditions that existed at the level of Medium Chad in the 1950s and 1960s. However, the 1970s and 1980s were characterized by severe droughts and the lake rapidly switched to Small Chad.

In regards to Baga Polder, the irrigation network that was set up covered overall only 1700 ha. The planned pumping station was never constructed and the project served only for temporary installations. In 1982, 400 ha were distributed among 100 production units. The last harvest was in 1983. In 1984, during a severe year of drought, water no longer reached the intake channel.

For SCIP it became necessary to extend the intake channel from the original 29 to $39 \mathrm{~km}$ in order to be able to irrigate 
the fields beyond the receding lake. Work began for phase 1 in 1975: of the 22000 ha programmed, 18000 were effectively prepared for cultivation. Rice was the first harvest in 1979. Phase 2 began in 1978 where the main infrastructures prepared 27000 ha but only 4000 were sown. The third phase remained only on paper as a hypothesis.

In the fields that were functioning, production progressively increased from 1979 to 1984 . The peak harvest of 10000 ha was reached in the 1983-1984 season with 3145 employed workers. The drastic recession of the lake, however, drained the structures that supplied water. Of the 14000 ha cultivated for the following season, almost to exorcize the advancement of a negative trend, nothing was harvested. The project stopped. When the water returned in 1988, the structures that were left inactive for such a long time were no longer working effectively. Much of the imported technology was too sophisticated and the impracticality of its usage had not survived during the period of interruption. Putting the machines back into productivity would have required important investments, which did not arrive. From time to time in the years that followed, the pumps were reactivated to irrigate areas of land that were, however, always more reduced (Adam, 2004; Bertoncin and Pase, 2012; Blench, 1997; Kalawole, 1987, 1988).

A presumption that is taken for granted is that the recession of water from the lake was responsible for the failure of these two projects. In reality, contemporaneous with the effects of drought, another factor played an important part in the breakdown of these projects: the economic crisis due to the drastic reduction of income from petroleum, which consequently lead to the abandonment of the modernization projects for agriculture by the Nigerian government. Moreover, other critical elements for failure were shared with the vast majority of other Sahelian irrigation mega-projects: in fact, some authors talk about "systematic failures" of the projects (Scott, 1998, 2010; Ika, 2005). Besides these concomitant causes, such as market fluctuations or diminished resources at the states' disposal due to the financial crisis, it is possible to identify at least three internal causes for the failure. The first regards the "shortsidedness" of the modern agricultural planning (Scott, 2010) and the incapacity to see what is happening outside of the boundaries of a narrow spatial and temporal horizon. It was not able to evaluate the negative effects that existed outside the perimeters of the projects (for example pollution of the water or removal of water for other usage, impact on local power structures, etc.) or over time (soil degradation, cost of maintenance, etc.). The second internal cause is the underestimation of the intrinsic fragility of complex systems and the strong interrelationship between the constitutive elements: the "various components are difficult to fit into place at the same moment: besides the construction of the irrigation works, land has to be distributed and settled, new crops have to be grown and new markets found" (Hirschman, 1967:43). The third internal cause is the repetitiousness of the work model "copy and paste" in dif- ferent realities, and the consequent incapacity to engage in a dialogue with diverse geographical and social situations. In a general sense, what is put into place by developers is a drastic simplification of the basic theories taken from science, modern agronomic technology and social engineering and which were then applied to the Sahelian land and people. This "one-commodity machine" (Scott, 2010) characteristic of the mega-irrigation projects is precisely based on a "heroic simplification" of the reality it imposed. The different boundaries of the territorial trap (physical, relational, cognitive and operative) create a very rigid structure: dams, dikes, embankments to contain the floods, perimeters around the fields, etc.; fixed organizational and social roles and centralized management; selection of "useful" expertise and the imposition of modern technology; and monoculture and constricting agronomic practices. The instruments of development are so systematically constraining and are not able to adapt to the changeable climatic conditions and adverse political and economic situations of the Sahelian states (Kalawole, 1989). The projects have revealed themselves to be effectively "traps": their mechanisms are jammed, the cages can no longer imprison and the boundaries can no longer exclude.

The rigidity of the territorial traps is opposite to what transpired in the traditional rural spaces that were characterized by mobility and flexibility (Gallais, 1984; Adams, 1993; Retaillé and Walther, 2011). The Sahelian population's response to the uncertainty of climatic conditions was elaborated over time and was tied to a form of use of resources that is both flexible and mobile: polyculture, burnbeating and itinerant cultivation, recessional agriculture, transhumance livestock breeding and integration with different activities such as fishing and craftsmanship. They are customs that adapt themselves more rapidly to market dynamics and are decisively more autonomous compared with political conventions. For every location and varying climatic condition that they face (such as drought, heavy rains, etc.), choices are made based on the most adaptable way to use the resources: tacit knowledge is activated, which is deeply embedded in specific situations.

During the continual crisis phases of the megadevelopment projects, the local people attempt to overcome the rigidity imposed by the irrigation schemes by reestablishing - through breaking the rules - those practices, the expertise and those relationships that were drastically abolished by the developers. For example, cultivated areas spread outside the project (yet using water from the project); the agronomic input (such as fertilizers) provided by technicians is used in the bush; ever more frequent illegal grazing exists within the irrigation borders; and fishing is practiced by closing the canals (Bertoncin and Pase, 2012).

The failure of these mega-projects also meant the collapse of one of the most expansive planning and regional development projects that had begun in the 1970s: the expectation for what was to be modernization of agriculture and state 
intervention turned into distrust and uncertainty. Indeed this failure is just one of any number of explanations for the complex economic and political crisis that afflicted the northeastern region in Nigeria since the turn of the millennium, and specifically Borno. The outbreak of insurgency is tied in particular to the politico-religious violence of Boko Haram and to the consequent, and often indiscriminate, repression of the police force and military (Pérouse de Montclos, 2014a, b).

The last section will explain what happened after the failure of the irrigation projects of Borno and how the local people try to escape from these territorial traps.

\section{Ubi fracassorium, ibi fuggitorium}

Today the Baga Polder and the SCIP are stretched as far as the eye can see with dark clay, cracked and dry, faintly scarred from what remains of the irrigation network. Inside the areas of the project improvised pumps irrigate a few hundred hectares. In the lower zones, where water accumulates from rainwater or inside the channels of the project, some farmers have returned to cultivating musakwa, an off-season grain. Many have emigrated somewhere else. Others have remained and are waiting, up to now in vain, that the large pumps will start up again.

However, after the great drought of the 1980s, the intake channels have started working again. In fact, it is in this area that agricultural activity has been the most productive. Along the intake channels, the farmers have set up small pumps to irrigate a variety of terrain. With the annual flooding from the lake, the water inundates the surrounding land. From January, the farmers begin to follow the floodwaters applying recessional cultivation (Kalawole, 1988; Sarch and Birkett, 2000; Bertoncin and Pase, 2012, 2015). In the dry season, small motor pumps have appeared allowing for the possibility to prolong land productivity and to bring the second season to a close. The fruitful harvest is then transported to markets in the state capital by utilizing the paths along the riverbanks and using the roads constructed for the projects. During the harmattan (dry) season, for tens of kilometres the two channels are flanked by irrigation cultivation that produces grains and plants and are managed autonomously by the farmers. The farmers have found a means of escape from the territorial trap by reinventing the infrastructures set in place by the project: planting where it was not expected, accessing water where it was not allowed, growing what was not permitted, utilizing the rivers banks as paths in order to reach the cultivable land of the lake, and navigating the intake channels with large canoes that allowed for exchanges with Chad and Cameroon. With the parts of the project that remained after the failure of the projects, the farmers knew how to reinvent an unexpected usage. They transformed the disaster into an opportunity. They re-appropriated their space, recuperating their tacit knowledge and taking advantage of important ex- pertise from the project (modern irrigation, new crops, etc.). The mega-project demonstrated in this way obduracy, indeed paradoxical: what remained was a point of departure for a new direction.

With failure, the farmers generated innovative solutions. As Pulcinella says, the renowned masqueraded Neapolitan from the Commedia dell'Arte, "ubi fracassorium, ibi fuggitorium": where there is catastrophe, there is also a means of escape. In a recent work of Agamben (2015), reference is made to the figure of Pulcinella. It begins with 104 plates from an album of drawings by Giandomenico Tiepolo, all of which are dedicated to the masqueraded Neapolitan and entitled Pulcinella ovvero Divertimento per li regazzi. Pulcinella (“A mask or a man? A god or a demon?"; Leogrande, 2015) is for Agamben the symbolic figure from an era of catastrophe: "Pulcinella appears when politics die" (Leogrande, 2015). In fact, Tiepolo produced his album between 1793 and 1797, which at the time marked the end of the Republic of Venice but also the end of political life for the Venetians. When facing a catastrophe, what matters is to search for a means of escape: "The secret of Pulcinella is that, in the comedy of life, there is no secret, but only, in each instant, a way to escape" (Agamben, 2015:130). Precisely for this reason Pulcinella is contemporary. Even today with the domination of an economic and technological paradigm we are in a time of catastrophe, or as is noted, an "eclipse of politics" (Agamben, 130). From this point of view, Pulcinella represents "an expression of another politic": "the paradigm of the struggle that has monopolized political imagination of modern times has to be substituted with that of escape" (Agamben), as did the farmers of Borno. As Pulcinella, who is both "inside and outside", the farmers were also inside and outside of the project, in and out of modern agricultural practices and in and out of the policies of development. In reference to the territorial trap, "What we are dealing with here is the liberation of that which remains captured and separated by means of apparatuses, in order to bring it back to a possible common use" (Agamben, 2009:17). The "profanation" of apparatuses, using their component parts in a "desecrating" and "detached" way, compared to the model (Agamben, 2015), was the means for them to remove themselves from the grip of the territorial trap. In this way, the farmers reestablish a "possible common use" to what had been limited by the boundaries of the project and usage that was withdrawn from the local population.

Attempts by the local population to find new and autonomous solutions for development clashed with the violence by the Islamic insurgency. The shores of the lake have been directly involved over these last years in conflicts between Boko Haram Islamic militants and the military forces: in particular, in April 2013 about 200 civilians were killed at Baga Kawa as a reprisal after the death of a soldier at a checkpoint. Warfare and seizure of arms took place many times in the villages on the lake. From August 2014, many refugees began to hide on some islands just over the border of Nige- 
ria and Chad to escape the violent clashes between the army and rebels. In January 2015, the attack at Baga Kawa was particularly serious and was carried out by Boko Haram. It ended up destroying a large part of the area and some villages nearby. This situation makes it impossible to have the latest reliable information as to what is happening in the area of Baga Polder and of the SCIP (Pourtier, 2015; Seignobos, 2015), even if the news reported numerous raids and plunder of the cultivated fields in the SCIP zone (e.g. Daily Post Nigeria, http://allafrica.com/stories/201306170476.html).

\section{Conclusions}

This paper sought to verify if it made any sense to transfer the concept of territorial trap (Agnew, 1994) from a comprehensive interpretation of modern political space and international relations onto a another scale (the internal one), that of the territorial development in a state. In particular, it proposed an interpretation of the Sahelian mega-irrigation projects as apparatuses of development and, more precisely, as territorial traps, further identifying four dimensions: physical, relational, cognitive and operative. In the selected case study, in the state of Borno (Nigeria), the irrigation projects clearly operated utilizing different boundaries, thus allowing for the possibility to observe how territorial traps function. The rigidity of the apparatuses was a determining factor in the crisis. These failures dismantled the "territorial trap" and left space for self-initiative on the part of the farmers, which they in turn integrated with modern knowledge and traditional expertise. Paradoxically, the obduracy of the project was maintained through the reutilization of some of its infrastructures in unexpected ways. We believe that the capability of the farmers "to desecrate the apparatus" (Agamben, 2009) and to find the "means of escape" (Agamben, 2015) readdresses the need for a more general understanding of the actual crisis in developmental policies and of the necessity to overcome the "territorial traps".

At the present time, the social and economic situation is so gravely deteriorated in Borno that even the minimum conditions for security and safety cannot be met. When these do change and a new window for investment and development is possible, the capabilities of the locals to find solutions and to adapt agriculture to an ever-changing environment must be taken into consideration. Startlingly enough, it seems that political decision makers persist with the idea of eventual mega-interventions: proposals such as a water transfer project from the Ubangi River to Lake Chad (Lemoalle and Magrin, 2014:171-174; Magrin, 2016) or the ongoing negotiations between the state of Niger and a Saudi private company (Al Horaish) for the development of a 74000 ha irrigation project in the region of Diffa (Tchangari and Diori, 2016) demonstrate that the failures of the past are not being taken into consideration.
Data availability. No data sets were used in this article.

Competing interests. The authors declare that they have no conflict of interest.

Acknowledgements. We would like to thank all of the interlocutors in our fieldwork: the farmers, the local people, the technicians of the development projects and the experts from the ministries and international development agencies. We are also thankful for the valuable suggestions and critical comments offered in the various stages of writing to Rony Emmeggener and Ola Söderström. In closing, we wish to thank the editor and the two anonymous revisers whose precise recommendations gave us the opportunity to enhance our subject matter.

Edited by: M. Houssay-Holzschuch

Reviewed by: two anonymous referees

\section{References}

Adam, M.: The Chad Basin Development Project. Rise and fall of a giant irrigation project in West Africa, in: Living with the lake, Perspectives on history, culture and economy of Lake Chad, Studien zur Kulturkunde, edited by: Krings, M., Platte, E., and Köppe, R., Köln, 191-203, 2004.

Adams, W. M.: Large scale irrigation in northern Nigeria: performance and ideology, Transactions of the Institute of British Geographers, New Series, 16, 287-300, 1991.

Adams, W. M.: Indigenous Use of Wetlands and Sustainable Development in West Africa, The Geographical Journal, 159, 209-218, 1993.

Agamben, G.: What is an apparatus?, Stanford University Press, Stanford, 2009.

Agamben, G.: Pulcinella ovvero Divertimento per li regazzi, nottetempo, Roma, 2015.

Agnew, J.: The Territorial Trap: the Geographical Assumptions of International Relations Theory, Review of International Political Economy, I, 53-80, 1994.

Agnew, J.: Still Trapped in Territory?, Geopolitics, 15, 779-784, 2010.

Agnew, J.: Revisiting the Territorial Trap, Nordia Geographical Publications, 44, 43-48, 2015.

Barnett, T.: The Gezira Scheme. An Illusion of Development, Frank Cass, London, 1977.

Bertoncin, M. and Pase, A.: Autour du lac Tchad. Enjeux et conflits pour le contrôle de l'eau, L'Harmattan, Paris, 2012.

Bertoncin, M. and Pase, A.: L'irrigation sur les rives nigérianes. Grands projets contrariés et hybridation contemporaine, in: Atlas du lac Tchad, edited by: Magrin, G., Lemoalle, J., and Pourtier, R., Passages, Paris, 107-109, 2015.

Bertoncin, M., Pase, A., Quatrida, D., and Turrini, S.: Territori dello zucchero: le dinamiche di prossimità nella Sugar Belt Sudanese, Rivista Geografica Italiana, 125, 93-114, 2017.

Blench, R.: The history and future of water management of the Lake Chad basin in Nigeria, in: L'homme et l'eau dans le bassin du lac 
Tchad, edited by: Jungraithmayr, H., Barreteau, D., and Seibert, U., ORSTOM, Paris, 143-166, 1997.

Boone, C.: Property and Political Order in Africa: Land Rights and the Structure of Politics, Cambridge University Press, New York, 2014.

Bouquet, C.: Insulaires et riveraines du lac Tchad: une étude géographique, I et II, L'Harmattan, Paris, 1990.

Brenner, N. and Elden, S.: Henry Lefebvre on State, Space, Territory, International Political Sociology, 3, 353-377, 2009.

Cowen, M. P. and Shenton, R. W.: Doctrines of Development, Routledge, London, 1996.

Elden, C.: Thinking Territory Historically, Geopolitics, 15, 757761,2010

Elden, S.: The Birth of Territory, The University of Chicago Press, Chicago, 2013.

FAO: South Chad Irrigation Project. Feasibility Study. Feasibility Report, Sir M. Macdonald and Partners, Hunting Technical Services. With seven technical annexes: I - Soil Survey and Land Classification (2 vol.); II - Population, Land Tenure and Rural Institutions; III - Hydrogeology, Hydrology and Climatology; IV - Agriculture; V - Engineering; VI - Organisation and Management; VII - Economics, 1973.

Ferguson, J.: The Anti-Politics Machine: 'Development', Depoliticisation and Bureaucratic Power in Lesotho, Cambridge University Press, Cambridge, 1990.

Foucault, M.: Dits et écrits, Gallimard, Paris, 1994.

Gaitskell, A.: Gezira. A Story of Development in the Sudan, Faber and Faber, London, 1959.

Gallais, J.: Hommes du Sahel. Espaces-temps et pouvoirs: le delta intérieur du Niger, Flammarion, Paris, 1984.

Galli, C.: Spazi politici, L'età moderna e l'età globale, il Mulino, Bologna, 2001.

Gellert, P. K. and Lynch, B. D.: Mega-projects as Displacements, International Social Science Journal, 175, 15-25, 2003.

Hirschman, A. O.: Development Projects Observed, The Brookings Institution, Washington, DC, 1967.

Hommels, A.: Studying Obduracy in the City: Toward a Productive Fusion between Technology Studies and Urban Studies, Sci. Technol. Human Value, 30, 323-351, 2005.

Ika, L. A.: La gestion des projets d'aide au développement: historique, bilan et perspective, Perspective Afrique, 1, 128-153, 2005.

Kolawole, A.: Environmental change and the South Chad Irrigation Project (Nigeria), J. Arid Environ., 13, 169-176, 1987.

Kolawole, A.: Cultivation of the floor of Lake Chad. A response to environmental hazard in Eastern Borno, Nigeria, The Geographical Journal, 154, 243-250, 1988.

Kolawole, A.: Underperformance of Nigerian irrigation systems. Design faults or system mismanagement?, Int. J. Water Resour. Develop., 5, 125-135, 1989.

Kuper, M.: Des destins croisés: regards sur 30 ans de recherces en grande hydraulique, Cah. Agric., 20, 16-23, 2011.

Lefebvre, H.: The production of space, Blackwell, Oxford UK, Cambridge USA, 1991.

Leogrande, A.: Dal disastro ci salverà la viltà di Pulcinella (intervista a G. Agamben), pagina ${ }^{99}$, novembre, 24-25, 2015.

Lemoalle, J.: Les différents états du lac Tchad, Un perpétuel changement, in: Atlas du lac Tchad, edited by: Magrin, G., Lemoalle, J., and Pourtier, R., Passages, Paris, 23-27, 2015.
Lemoalle, J. and Magrin, G. (Eds.): Development of Lake Chad, Current Situation and Possible Outcomes, IRD, Marseille, 2014.

Magrin, G.: De longs fleuves tranquilles? Les mutations des plaines refuges du bassin du lac Tchad, in: Des fleuves entre conflits et compromis, Essais d'hydropolitique africaine, edited by: Raison, J.-P. and Magrin, G., Paris, Khartala, 125-172, 2009.

Magrin, G.: The disappearance of Lake Chad: history of a myth, J. Polit. Ecol., 23, 204-222, 2016.

Maïga, M.: Le bassin du fleuve Sénégal, De la Traite négrière au Développement sous-régional auto-centré, L'Harmattan, Paris, 1995.

Morabito, V.: L'Office du Niger au Mali, d'hier à aujourd'hui, Journal des africanistes, 47, 53-82, 1977.

Morabito, V.: Cinquante années de riziculture irrigue à l'Office du Niger (Mali), in: Les rizicultures de l'Afrique de l'Ouest, Partie II: Les modèles irrigués exogènes, edited by: Cheneau Loquay, A. and Leplaideur, A., CIRAD, Montpellier, 113-119, 1995.

Newman, D.: Territory, Compartments and Borders: Avoiding the Trap of the Territorial Trap, Geopolitics, 15, 773-778, 2010.

Ogunbameru, B. O.: Socio-economic impact of South Chad Irrigation Project on participating farmers in Borno State, Annals of Borno, III, 137-145, 1986.

Pascon, P.: De l'eau du ciel a l'eau d'État, Psychosociologie de l'irrigation, Hommes, Terre et Eaux, 8, 3-10, 1978.

Pérouse de Montclos, M.-A.: Nigeria's Interminable Insurgency? Addressing the Boko Haram Crisis, Chatam House, London, 2014a.

Pérouse de Montclos, M.-A. (Eds.): Boko Haram: Islamism, Politics, Security and the State in Nigeria, Africa Studies Centre (ASC), Institut Français de Recherche en Afrique (IFRA), Leiden, 2014b.

Polanyi, M.: The Tacit Dimension, London, Routledge and Kegan, 1966.

Pourtier, R.: Le lac Tchad sous la menace de Boko Haram, in: Atlas du lac Tchad, edited by: Magrin, G., Lemoalle, J., and Pourtier, R., Passages, Paris, 162-163, 2015.

Quatrida, D.: Lo sviluppo ambiguo: nuovi progetti sulla terra ma per chi? Riflessioni a partire dal caso maliano, Geotema, 48, 71-79, 2015.

Reid-Henry, S.: The Territorial Trap Fifteen Years On, Geopolitics, 15, 752-756, 2010.

Retaillé, D. and Walther, O.: Spaces of Uncertainty: A Model of Mobile Space in the Sahel, Singapore Journal of Tropical Geography, 32, 85-101, 2011.

Sarch, M. T. and Birkett, C.: Fishing and farming at Lake Chad: Responses to Lake-level Fluctuations, The Geographical Journal, 166, 156-172, 2000.

Sautter, G.: Libres réflexions sur les aménagements ayant pour objet la maitrise de l'eau par ou pour les agricultures, Les Cahiers de la Recherche Développement, 14-15, 5-14, 1987.

Seignobos, C.: Boko Haram et le lac Tchad. Extension ou sanctuarisation?, Afrique contemporaine, 3, 93-120, 2015.

Scott, J. C.: Seeing Like a State. How Certain Schemes to Improve the Human Condition Have Failed, Yale University Press, New Haven and London, 1998.

Scott, J. C.: The Trouble with the View from Above, Website Cato Unbound, available at: http://www.cato-unbound.org/2010/ 09/08/james-c-scott/trouble-view-above (last access: July 2015), 2010. 
Shah, N.: The Territorial Trap of the Territorial Trap. Global Transformation and the Problem of the State's Two Territories, International Political Sociology, 6, 57-76, 2012.

Sidaway, J. D.: Spaces of Postdevelopment, Prog. Human Geogr., 31, 345-361, 2007.

Stanek, L.: Space as a Concrete Abstraction: Hegel, Marx and Modern Urbanism in Henri Lefebvre, in: Space, Difference, and Everyday Life: Henri Lefebvre and Radical Politics, edited by: Goonewardena, K., Kipfler S., Milgrom, R., and Schmid, C., Routledge, New York, 62-79, 2008.
Tchangari, A. T. M. and Diori, I.: Convoitises foncières dans le bassin du lac Tchad au Niger, Rapport de l'Observatoire du droit à l'alimentation au Niger, Alternative Espaces Citoyens, Niamey, Décembre 2016. 